Kocaeli Journal of Science and Engineering

\title{
Evaluation of Industry 4.0 Applications for Agriculture using AHP Methodology
}

\author{
Melda Güliz ATEŞ ${ }^{1}$ (D) , Yıldız ŞAHIN ${ }^{2, ~ * ~(D) ~}$ \\ ${ }^{1}$ Industrial Engineering, Kocaeli University, Kocaeli, 41100,Turkey, ORCID: 0000-0002-2243-9642 \\ ${ }^{2}$ Industrial Engineering, Kocaeli University, Kocaeli, 41100,Turkey, ORCID: 0000-0002-6283-5340
}

\begin{tabular}{l} 
Article Info \\
\hline Research paper \\
Received : July 15, 2020 \\
Accepted : February 6, 2021
\end{tabular}

Keywords

Agriculture

Agriculture 4.0

AHP

Industry 4.0

Industry 4.0 Applications

\section{Abstract}

\section{Introduction}

Industry 4.0 represents the newest level of digital solutions offered by new production understanding and current technological developments, where concepts of speed, flexibility, efficiency, cost and innovation come to the fore. With increasing competition and changing customer expectations in today's world, companies should shorten their time to market, be flexible and increase their efficiency in order to achieve sustainable success. At this point, Industry 4.0 creates new production processes that communicate with each other, collect and process real-time big data and make decisions with autonomous mechanisms. ${ }^{1}$ Cyber-physical systems aim to create "Smart Factories" of Industry 4.0 which includes the Internet of Things (IoT) and cloud computing technology [1]. In smart factories, cyber-physical systems observe physical processes, create a virtual copy of the physical world and make the final decision through distributed decision mechanisms. With IoT technology, cyber-physical systems communicate with each other and machine-machine, machine-human

${ }^{*}$ Corresponding Author: meldaguliz.ates@kocaeli.edu.tr collaborations are established in real-time, and instant data and information are transmitted to internal and external participants in the value chain of the organization through internet services [2].

Industry 4.0 refers to the 4 th Industrial Revolution, which includes intelligent, connected and decentralized production (Figure 1). The first industrial revolution (Industry 1.0) emerged with the introduction of steam power in mechanical systems. The second industrial revolution (Industry 2.0) started with electricity, assembly lines and mass production. The third industrial revolution (Industry 3.0) was accomplished by replacing people working in the production line of computerized production and automation, robots and machines, and the introduction of information technologies. Today, with the fourth industrial revolution (Industry 4.0), computers and automation come together with a brand-new structure and equipped with machine learning algorithms, computer systems control robots with a minimum human contribution [3].

The concept of Industry 4.0 was first mentioned at the Hannover Fair in Germany in 2011 and Germany and the 
US, which lost their production power to countries like China and India, determined this reducing manpower impact on the production model as their new industrial strategy [4].

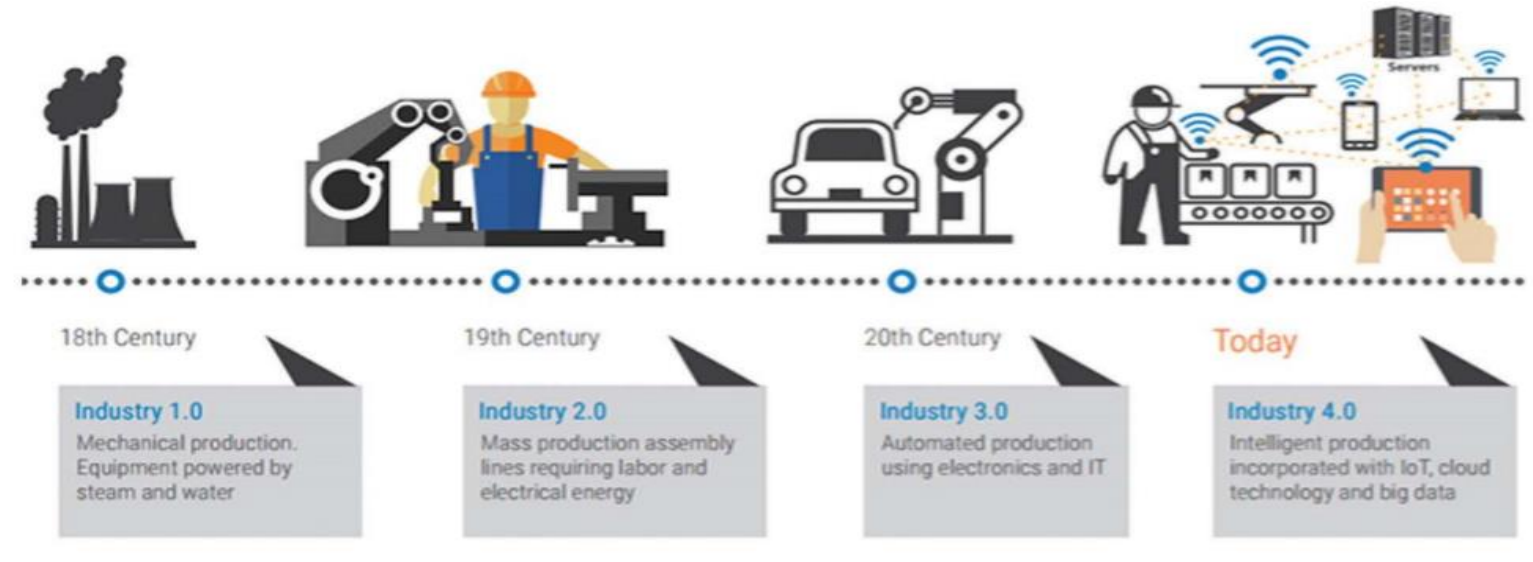

Figure 1. Industrial revolutions (Source [3])

In this context, the agriculture sector, like other sectors, adapts to the changing conditions within the scope of Industry 4.0, and the concept of Agriculture 4.0, which includes digital agricultural technologies, appears. This transformation is actually a necessary step to take against the threats expected in the future, because the world population will be more than 9.6 billion by 2050 , according to the report titled "World Population Expectation" prepared by the United Nations (UN). That will cause a $70 \%$ increase in food consumption and also agricultural production is projected to decrease by $2 \%$ in the next decade, as 12 million agricultural lands deteriorated every year. The observations of the last five years indicate the loss of an average of 5.2 million hectares of forest land each year [5]. Smart and sustainable agriculture practices with Agriculture 4.0 technologies aim to be environmentally friendly, to achieve high productivity with fewer resources, and to be economical and practical.

In this study, the transition process from Industry 4.0 to Agriculture 4.0 and new technologies related to digital agriculture will be discussed, and the evaluation of digital agriculture technologies with the analytical hierarchy process (AHP) method will be carried out according to the cost, income, applicability and practicality criteria.

\subsection{From Industry 4.0 to Agriculture 4.0}

In the age of Industry 4.0, digital technologies developed and used thanks to the integration of data and the connectivity of their resources have developed highly efficient and sustainable production models. A more efficient and sustainable structure in the agricultural sector is considered as a natural result of the transfer of the Industry 4.0 approach to this sector [6]. As expected, the agricultural sector is changing like other sectors and is becoming much more technology and knowledge-intensive. Behind this, the concern of offering sustainable and affordable prices and more crops to the growing population with fewer resources in the coming periods lies and digital/smart agriculture principles are offered as a solution to this problem [7-8]. Traditional production methods turn into modern, productive and innovative forms, farmers realize the increasing importance of managerial activities and harmony with nature as well as production [9]. The meaning of the agricultural sector today shifted to smart agriculture, nature-friendly and water-saving agriculture, efficient agriculture and digital agriculture is the most necessary, effective and most appropriate approach for this transformation [10].

Digital agriculture is not the result of an instantly developing process, it has followed a path parallel to the development stages of the industrial revolution and this process has brought us to today's "Agriculture 4.0" [1]:

-Agriculture 1.0: It is a labor-intensive and lowyielding form of agriculture carried out with animal power in the early 20th century.

- Agriculture 2.0: Started with the use of combustion engines and tractors in agriculture, another feature of this period is high volume production with synthetic pesticides and fertilizers with low cost.

- Agriculture 3.0: Precision agriculture practices started with the opening of military GPS (Global Positioning System) signals for public use. Precision agriculture is defined as the management of variability in order to increase productivity and minimize the impact of environmental factors. With GPS signals and satellite images, terrain features, organic matter contents, moisture and nitrogen levels, crop efficiency, etc. can be measured. Similarly, decision support systems and agricultural software related to instant maps have been developed.

- Agriculture 4.0: In the 2010s with the development 
of cheap and advanced sensors, actuators, microprocessors; high bandwidth in the cellular communication system; cloud-based information communication technology and big data analytics leaded connected agricultural practices.

\section{System of Systems}

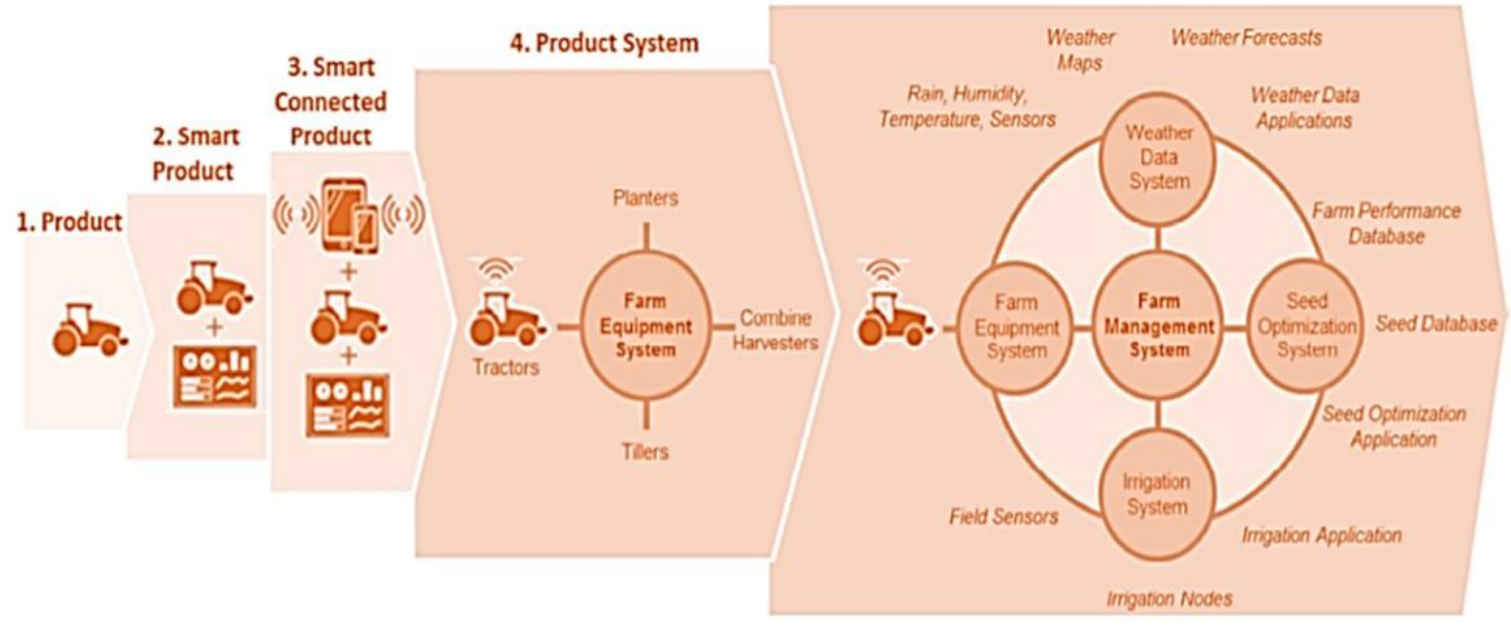

1

Digital agriculture, as a knowledge-based agriculture model, provides support to the manufacturer in management of resources, the efficiency of business operations and decision making by the collection and processing of high-precision, instant and personalized data with the technological tools offered by Industry 4.0, How agricultural components come together in the Agriculture 4.0 concept is summarized in Figure 2.

Internet of Things (IoT), one of the most important technologies of Industry 4.0, is the main component of the related agricultural practices in Agriculture 4.0. IoT is based on the natural environment and any measurable physical size, such as temperature, humidity, $\mathrm{pH}$, gas rates, light intensity. The raw data collected by various sensors placed in the product area are transmitted to cloud computing systems for storage using wireless gateways or other methods required for human-machine, machinemachine communication. The data in the cloud environment is transmitted to the farmers so that they can make better decisions directly or by processing [8-12]. With sensor technology, farmers are given detailed information on the fertilizer type they need to use, weather and soil conditions, irrigation and mineral amount, estimated harvest time, and this way, it is aimed to obtain high-level efficiency by managing their resources correctly [13]. An exemplary study on reducing water consumption with IoT was carried out with Bosh smart technology used in olive groves in Spain. With the wireless sensors placed on the trees, precise irrigation is made according to the weather conditions and actual needs. Similarly, Rajakumar [14] and Kumar and Ramasamy [15] have developed digital systems that automatically start and shut off irrigation if the humidity level is low with the soil moisture sensor and instantly transfer the current measurements via the IoT module. Again, by monitoring the soil properties and environmental factors with sensors, studies to find the ideal environment conditions for systems and plants that take automatic action have become prominent in recent years [16-17]. Another usage area of IoT and sensors is the monitoring of livestock and animal products [13-16]. With RFID technology counting and monitoring of animals, keeping the statistics in the process from birth to sale and providing security with the tracking mechanism has become extremely easy [18]. German CLASS company proposes a proactive approach by informing the producers via SMS with sensors attached to animals during pregnancy or disease situations. Following the herd with the Connected Herd Management application, the animal herds can be followed instantly [19]. The use of IoT in the agricultural sector has increased the functionality of the existing tools by making the physical environment a part of the information flow, and the collection and processing of a wide variety of information have accelerated the development of the agricultural sector from greenhouse to animal husbandry [20]. According to the research carried out by Business Insider, while 30 million objects in agriculture are interconnected in 2015, this figure is projected to increase to 75 million in 2020, which also indicates a $20 \%$ growth in the economy.

According to the report published by the United Nations, two-thirds of the population will live in urban areas by 2050, which will reduce its agricultural workforce potential. The importance of autonomous systems, one of the new digital solutions to reduce the workload of farmers, is increasing with this statistic. With the developing object detection and radar technology, the developments in autonomous vehicle technology increase the applicability and decrease the costs. Robotic and autonomous vehicles, 
which are among the components of Industry 4.0, have been transferred to the agriculture sector in a similar way, and agricultural vehicle applications that automatically recognize and talk to each other have started to appear with Agriculture 4.0 [11]. Agricultural robots aim to increase productivity by automating standardized and repetitive work (such as harvesting, mowing, pruning, seeding, spraying, phenotyping, packaging) for farmers [21]. While autonomous systems in agriculture and robotics are defined as the application process of robotics, automatic control and artificial intelligence techniques in all kinds of agricultural production -including farmbots and farm drones- one of the most important technologies is drones, which are small unmanned vehicles with cloud connections and cameras [12-13]. Drones, which can display the entire production area and take instant action, as well as carry loads such as fertilizer, water, increase work efficiency and reduce costs. In the Agriculture 4.0 report published by Oliver Wyman in 2018, drones have given wide coverage and usage areas of this technology shared as 3-D mapping, soil and field analysis, providing data for the best planting area decision, sowing, fertilizing, irrigation, spraying activities, harvest imaging and harvest health screening. Hektaş agriculture firm in Turkey started to collect significant information on optimum plant growing conditions via drone and sensor technology and create a library by analyzing the collected information [22].

\section{Materials and Methods}

The development of digital agriculture in our country has started to be supported by state policies, and an action plan and roadmap have been created for the Agriculture 4.0 transformation. The number of producers that support and nurture this strategy and keep pace with digital transformation is increasing. Thus, the decision to make the right technology investment for the manufacturer is becoming more and more critical day by day. As what kind of factors or variables need to be considered for agricultural policy and decision-makers is a challenging topic mostly economical and technical factors have been seen as the main criteria for agricultural investment decisions [23-25]. In this context, an AHP study based on cost, income, applicability and practicality criteria is conducted for both agriculture and animal husbandry sectors.

\subsection{Analytical Hierarchy Process (AHP)}

Analytical Hierarchy Process (AHP) was designed by Thomas L. Saaty in the 1970s to solve complex decisionmaking problems involving multiple criteria. AHP is based on analyzing the problem with a hierarchical model consisting of goals, criteria and alternatives and reaching the appropriate solution with pairwise comparisons. It is an approach that can solve large-scale, dynamic and complex multi-criteria decision-making problems [26]. The stages of the AHP method can be summarized as [27]:

-Defining the problem, determining the main goal

-Determination of decision criteria

-Determination of decision alternatives

-Creating the hierarchical structure of the problem

-Pairwise comparison of criteria

-Pairwise comparison of alternatives and calculation of their priorities according to criteria

-Selection of the highest priority alternative

The scale 1-9 of Saaty is used to perform pairwise comparisons (Table 1), and to determine whether the comparisons are consistent, the consistency ratio (CR) should be calculated for each matrix after the comparison matrices are configured. However, if the CR value is less than 0.10 , pairwise comparisons can be said to be consistent and the highest priority alternative can be decided.

Table 1. The comparison scale in AHP (Source [28])

\begin{tabular}{|c|l|}
\hline $\begin{array}{c}\text { Importance } \\
\text { Level }\end{array}$ & \multicolumn{1}{c|}{ Definition } \\
\hline 1 & Equal importance \\
\hline 3 & Weak impotance of one over another \\
\hline 5 & Essential or strong importance \\
\hline 7 & Demonstrated importance \\
\hline 9 & Absolute importance \\
\hline $2,4,6,8$ & $\begin{array}{l}\text { Intermediate values between the two } \\
\text { adjacent judgements }\end{array}$ \\
\hline
\end{tabular}

\subsection{Hierarchy Models and Application}

Following the process steps of the AHP method, two separate applications were carried out for the agriculture and animal husbandry sectors.

-In the determination of the main target, which is the first step, the target has been defined as "Selection of the best Agriculture 4.0 technology for the agriculture sector" and "Selection of the best Agriculture 4.0 technology for animal husbandry sector".

-Both literature review and expert opinions were consulted during the determination of criteria and alternatives, where the criteria were determined as cost, return, applicability and practicality for both sectors (with different weights). While the alternatives for the agricultural sector were a drone, soil sensor and autonomous tractor technology, animal sensor, associated herd application and milk scanner technology alternatives 
were evaluated for the animal husbandry sector.

-Pairwise comparisons were made by three experts, who are academics with $\mathrm{PhD}$ in the agricultural area. Experts opinions were collected via mailing (as an excel sheet) with the request of pairwise comparison of criteria and pairwise comparison of alternatives and calculation of their priorities according to criteria. Expert evaluations were singularized using the geometric mean method and a compromise value was obtained.

-Super Decisions package program was used in the implementation of the AHP method.

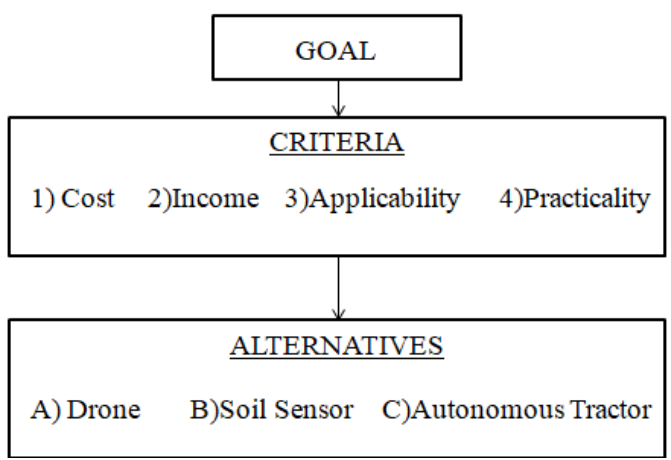

Figure 3. Hierarchy model for agriculture

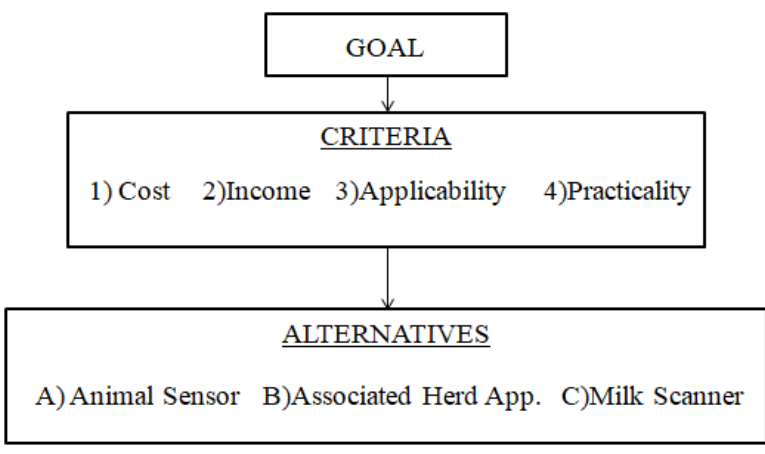

Figure 4. Hierarchy model for animal husbandry

\section{Results and Discussion}

According to the analysis conducted with Super Decisions software, the priority values for criteria and rankings of alternatives have been obtained for two sectors. For agriculture income was found as the most important criteria and followed by the criteria cost, applicability, practicality respectively. Similarly, despite the different limiting values, the orders of the criteria for animal husbandry have been obtained as income, cost, applicability, practicality respectively. In the selection of the best alternative, the soil sensor, one of the Agriculture 4.0 technologies for the agricultural sector, came to the fore with its cost advantage and applicability and was chosen as the best alternative within the criteria. Similarly, for the animal husbandry sector, it was decided on the sensor technology attached to the animals as the best alternative with its cost advantage and the ability to provide fast returns.

Table 2. Priorities of criteria for agriculture

\begin{tabular}{|l|l|l|}
\hline Criteria & $\begin{array}{l}\text { Normalized by } \\
\text { Cluster }\end{array}$ & Limiting \\
\hline Income & 0,564 & 0,282 \\
\hline Cost & 0,255 & 0,128 \\
\hline Applicability & 0,113 & 0,056 \\
\hline Practicality & 0,068 & 0,034 \\
\hline
\end{tabular}

Table 3. Priorities of criteria for animal husbandry

\begin{tabular}{|l|l|l|}
\hline Criteria & Normalized by Cluster & Limiting \\
\hline Income & 0,503 & 0,251 \\
\hline Cost & 0,285 & 0,143 \\
\hline Applicability & 0,114 & 0,057 \\
\hline Practicality & 0,098 & 0,049 \\
\hline
\end{tabular}

Table 4. Results for alternatives for agriculture

\begin{tabular}{|l|l|l|l|l|}
\hline Alternatives & Ideal & Normal & Raw & Rank \\
\hline Soil Sensor & 1 & 0,575 & 0,287 & 1 \\
\hline Drone & 0,562 & 0,323 & 0,161 & 2 \\
\hline $\begin{array}{l}\text { Autonomous } \\
\text { Tractor }\end{array}$ & 0,179 & 0,103 & 0,051 & 3 \\
\hline
\end{tabular}

Table 5. Results for alternatives for animal husbandry

\begin{tabular}{|l|l|l|l|l|}
\hline Alternatives & Ideal & Normal & Raw & Rank \\
\hline Animal Sensor & 1 & 0,465 & 0,233 & 1 \\
\hline Milk Scanner & 0,643 & 0,299 & 0,15 & 2 \\
\hline $\begin{array}{l}\text { Associated } \\
\text { Herd } \\
\text { Application }\end{array}$ & 0,506 & 0,235 & 0,117 & 3 \\
\hline
\end{tabular}

\section{Conclusions}

Due to the paradigm shift based on changing customer demand and expectations for gaining competitive advantage companies focused on being flexible, fast and efficient. Industry 4.0 applications serve these needs with their digitalized tools and emerge as a concept that increases its popularity. Similarly, the agriculture sector adapts to changing conditions within the scope of Industry 4.0, and the Agriculture 4.0 concept, which includes digital agriculture technologies, stands out especially in terms of optimum use of resources in the face of expected population growth. In this study, the transition process from Industry 4.0 to Agriculture 4.0 and new technologies 
of digital agriculture are mentioned.

Although there are studies that presents conceptual frameworks on Agriculture 4.0, need for analytical approaches on the area is emerging. In this context, this study aims to close a gap by presenting an AHP based decision making approach on digital agriculture technologies for agriculture and animal husbandry sectors. For the decision-making process criteria were obtained as income, cost, applicability and practicality due to the literature review and field experts' opinion. Similarly, alternatives for digital solutions were gathered from literature and chosen with field experts. As the result of the study, it has been decided that soil sensor technology is the best alternative for the agricultural sector, where the technological infrastructure and the availability of the necessary information bring the cost advantage. Similarly, in the animal husbandry sector, the sensor technology attached to the animals is obtained as the best alternative with its cost advantage and fast return.

When the outputs of the study are considered from a managerial point of view, it has come to the forefront that the income and cost balance (criteria) have priority at the investment point. At this point, it is usual to proceed with an alternative that can provide a fast return on investment and offer a cost advantage. While sensor technology is the backbone of Agriculture 4.0, it has become the top priority alternative with the cost advantage of its prevalence and applicability.

\section{Conflict of Interests}

No conflict of interest was stated by the authors.

\section{Declaration of Ethical Standards}

The authors of this article declares that the materials and methods used in this study do not require ethical committee permission and legal-special permission.

\section{References}

[1] Kovács, I., Husti, I., 2018. The role of digitalization in the agricultural 4.0 - how to connect the industry 4.0 to agriculture?. Hungarian Agricultural Engineering, pp.38-42.

[2] Tong-Ke F., 2017. Smart Agriculture Based on Cloud Computing and IOT. Journal of Convergence Information Technology, 8(2), pp.210-216.

[3] Husti, I., Daroczi, M., Kovacks, I., 2017. Towards sustainable agriculture and biosystems engineering book Edited by: Anikó Nyéki, Attila J. Kovács, Gábor Milics.
[4] EBSO, 2015. Sanayi 4.0. Retrieved from http://www.ebso.org.tr/ebsomedia/documents/sanayi40_88510761.pdf

[5] Kirkaya, A., 2020. Ak1llı tarım teknolojileri uygulamalar1. Retrieved from https://www.researchgate.net/publication/339029285 _AKILLI_TARIM_TEKNOLOJILERI_UYGULAM ALARI

[6] Corallo, A., Latino, M.E., Menegoli, M., 2018. From Industry 4.0 to Agriculture 4.0: A Framework to Manage Product Data in Agri-Food Supply Chain for Voluntary Traceability. World Academy of Science, Engineering and Technology, International Journal of Nutrition and Food Engineering, 12, pp.146-150.

[7] Ozdogan, B., Gacar, A., Aktaş, H., 2017. Digital Agriculture Practices in The Context of Agriculture 4.0. Journal of Economics, Finance and Accounting. 4. 184-191. 10.17261/Pressacademia.2017.448.

[8] Duman, B., Ozsoy, K., 2019. Endüstri 4.0 perspektifinde akıllı tarım. Retrieved from https://www.researchgate.net/publication/334234038 _ENDUSTRI_40_PERSPEKTIFINDE_AKILLI_TA RIM_SMART_AGRICULTURE_IN_INDUSTRY_4 0_PERSPECTIVE

[9] Sørensene, C. G., Fountas, S., Nash, E., Pesonen, L., Bochtis, D., Pedersen, S. M., Basso, B., Blackmore, S. B., 2010. Conceptual Model of a Future Farm Management Information System, Computers and Electronics in Agriculture, 72(1), pp.37-47.

[10] Yane, D., 2010. Research and Analysis about System of Digital Agriculture Based on a Network Platform, In International Conference on Computer and Computing Technologies in Agriculture, Springer Berlin Heidelberg. pp.274-282.

[11] Zambon, I., Cecchini, M., Egidi, G., Saporito, M., Colantoni, A., 2019. Revolution 4.0: Industry vs. Agriculture in a Future Development for SMEs. Processes. 7. 36. 10.3390/pr7010036.

[12] Kalkışım, A., Akkaş, M., Yucedag, I., 2019. Nesnelerin İnterneti ve Nesnelerinin İnternetinin Tarım Alanında Kullanımı. Retrieved from https://www.researchgate.net/publication/336020647 _NESNELERIN_INTERNETI_VE_NESNELERIN_ INTERNETININ_TARIM_ALANINDA_KULLANI MI

[13] Kilavuz, E, Erdem, İ., 2019. Dünyada Tarım 4.0 Uygulamaları ve Türk Tarımının Dönüşümü. Social Sciences, 14(4), pp.133-157. 
[14] Rajakumar, G., Sankari, M.S., Shunmugapriya, D., Maheswari, S.P.U., 2018 Iot Based Smart Agricultural Monitoring System", Asian Journal of Applied Science and Technology (AJAST), 2(2), pp.474-480.

[15] Kumar, V., Ramasamy, R., 2017. Implementation of Iot In Smart Irrigation System Using Arduino Processor", International Journal of Civil Engineering and Technology (IJCIET).

[16] Meola, A., 2016. Why IoT, big data \& smart farming are the future of agriculture,

https://www.businessinsider.com/internet-of-thingssmart-agriculture-2016-10.

[17] Suma, N., Samson, S.R., Saranya, S., Shanmugapriya, G., Subhashri, R., 2017. IOT Based Smart Agriculture Monitoring System" International Journal on Recent and Innovation Trends in Computing and Communication, 5(2), pp.177-181.

[18] Doknić, V., 2014. Internet of Things Greenhouse Monitoring and Automation System, Summer term.

[19] Akay, M., 2018. Endüstri 4.0 ile Akıllı Tarıma Geçiş. Retrieved from https://www.researchgate.net/publication/326550785 _ENDUSTRI_40_ILE_AKILLI_TARIMA_GECIS

[20] Kaloxylos, A., Eigenmann, R., Teye, F., Politopoulou, Z., Wolfert, S., Shrank, C., Dilinger, M., Lampropoulou, I., Antoniou E., Pesonen, L., Nicole, H., 2012. Farm Management Systems and The Future Internet Era, Computers and Electronics in Agriculture, 89, pp.130-144.

[21] Oliver Wyman Report., 2018. Agriculture 4.0: The Future of Farming technology.

[22] Kirkaya, A., 2020. Akıllı tarım teknolojileri uygulamalar1. Retrieved from https://www.researchgate.net/publication/339029285 _AKILLI_TARIM_TEKNOLOJILERI_UYGULAM ALARI

[23] Yanli, Z., 2009. An Introduction to the Development and Regulation of Agricultural Insurance in China. Geneva Pap. Risk Insur. Issues Pract., 34, pp.78-84.

[24] Pinstrup-Andersen, P., Shimokawa, S., 2006. Rural Infrastructure and Agricultural Development; World Bank: Washington, DC, USA. Avaliable online: http://siteresources.worldbank.org/INTDECABCTO K2006/Resources/Per_Pinstrup_Andersen_Rural_Infr astructure.pdf

[25] Amadi, B.C., 1998. The impact of rural road construction on agricultural development: An empirical study of Anambra state in nigeria. Agricultural System, 27, pp.1-9.

[26] Kaplan, R., 2010. “AHP Yöntemiyle Tedarikçi Seçimi: Perakende Sektöründe Bir Uygulama”, Master's Thesis (Yüksek Lisans Tezi), İstanbul Teknik Üniversitesi, Fen Bilimleri Enstitüsü, İstanbul.

[27] Esen, H. Ö., 2008. "Applied Operational Research" ("Uygulamalı Yöneylem Araştırması"), (S. Tolun, Ed.), Çağlayan Kitabevi. 